\title{
Feszes íny szélesítés implantátumok körül - „H” technika esetismertetés
}

\author{
DR. PÁRKÁNYI LÁSZLÓ*, DR. FRÁTER MÁRK**
}

\begin{abstract}
Míg a természetes fogak körül a gingiva vastagságának és a feszes íny jelenlétének inkább csak esztétikai jelentősége van, addig a koronai restaurátummal ellátott implantátumok körül a lágyszöveti viszonyok nem csak az implantációs pótlások esztétikai megjelenését, hanem akár az implantátumok hosszú távú sikerességét is befolyásolhatják. Implantátumok mellett hagyományosan a biotípus-módosítás, illetve keratinizált szövetszélesítés külön sebészi beavatkozás eredménye. Ez megtörténhet az implantátum felszabadítása előtt vagy azt követően. A beavatkozáshoz alkalmazott graft rendszerint szabad íny graft (Free Gingival Graft, FGG), mely jelentős donor morbiditást jelenthet, valamint az esztétikájában, megjelenésében eltér a környező lágyszövetekétől. Jelen technika célja a biotípus módosítása és keratinizált szövet szélesítésének elvégzése egyazon lépésben az implantációval, kötőszövet-helyettesítő kollagén mátrix (Acellular dermal matrix, ADM) alkalmazásával, nyitott gyógyulás során. Ezzel egyszerre csökkenthető a donor morbiditás, a sebészi beavatkozások száma (ezáltal a gyógyulási idő), valamint javítható az esztétikai végeredmény.
\end{abstract}

Kulcsszó: feszes íny szélesítés, ADM, kollagén mátrix, tunnel-technika

\section{Bevezetés}

Napjainkban bizonyított tény, hogy implantációs helyreállítások esetében kiemelt jelentőséggel bírnak az implantátumok körüli lágyszövetek mind mennyiségi, mind minőségi szempontból [15]. Bár a megfelelő esztétikához is nagymértékben hozzájárul az ideális lágyszövet környezet [4, 9], az implantátum sikeressége szempontjából ennél jóval lényegesebb befolyásuk is van, ezáltal az esztétikai zónán kívül is nagy fontossággal bírnak. A periimplantáris mucosa vastagságának közvetlen hatása van a marginális lágyszövet stabilitására, valamint az alatta levő csont megtartásában is $[6,8]$. A keratinizált, és ezen belül is legfőképpen a feszes mucosa ugyancsak nagyban hozzájárul az egészséges periimplantáris szövetek fenntartásához, többek között a marginális csontszint stabilizálásával [2, 11]. Bár a keratinizált mucosa hiánya nincsen egyértelmúen bizonyított összefüggésben a periimplantáris gyulladásos kórképek kialakulásával, az individuális szájhigiéne befolyásolásán keresztül azonban mindenképpen összefügg ezen folyamatokkal is [17, 3, 14].

\section{Háttér}

Fogak elvesztését követően a gyógyulás során az állcsontgerinc változó mértékű resorptión megy keresztül, mely főleg a horizontális dimenziót érinti [13]. Az állcsont involutio sohasem korlátozódik a keményszövetekre, minden esetben a lágyszövetekben is volumen-, illetve keratinizáció-csökkenés történik [1]. A fogvesztések (akár kariológiai, akár parodontális okokból) legtöbb esetben elsőként a moláris régióban következnek be [12]. A keratinizált szövet csökkenése különösen kifejezett a moláris régióban, így moláris implantátumon rögzülő restaurátumok körül többször figyelhető meg annak jelentős hiánya [5]. A moláris régió a páciens számára nehezebbem hozzáférhető, így eleve a legnehezebben tisztítható terület. Implantátumok esetében adott menynyiségű plakk hatására könnyebben indul el gyulladásos folyamat a periimplantáris mucosa mentén, mint megtartott fogazat mellett a gingiva területén $[17,16]$.

\section{Kezelési koncepció}

Az alább ismertetett kezelés lényege a lágyszövetek vastagságának és keratinizációjának helyreállítása implantátumok körül, az implantációval egyazon sebészi lépésben [7]. Az invazivitást csökkentve, nyitott sebgyógyulás mellett, a gyógyulási felépítmények aktív szerepet játszanak a sebészi technikában. Továbbá, a mútét morbiditását csökkentve, saját kötőszövet nem kerül felhasználásra, a mucosa vastagítása és a keratinizáció növelése térhálós kollagén mátrixszal történik [10].

\section{Esetismertetés}

A középkorú hölgy páciensünk azért érkezett rendelőnkbe, hogy bal alsó laterális foghiányát pótoltassa. A páci- 

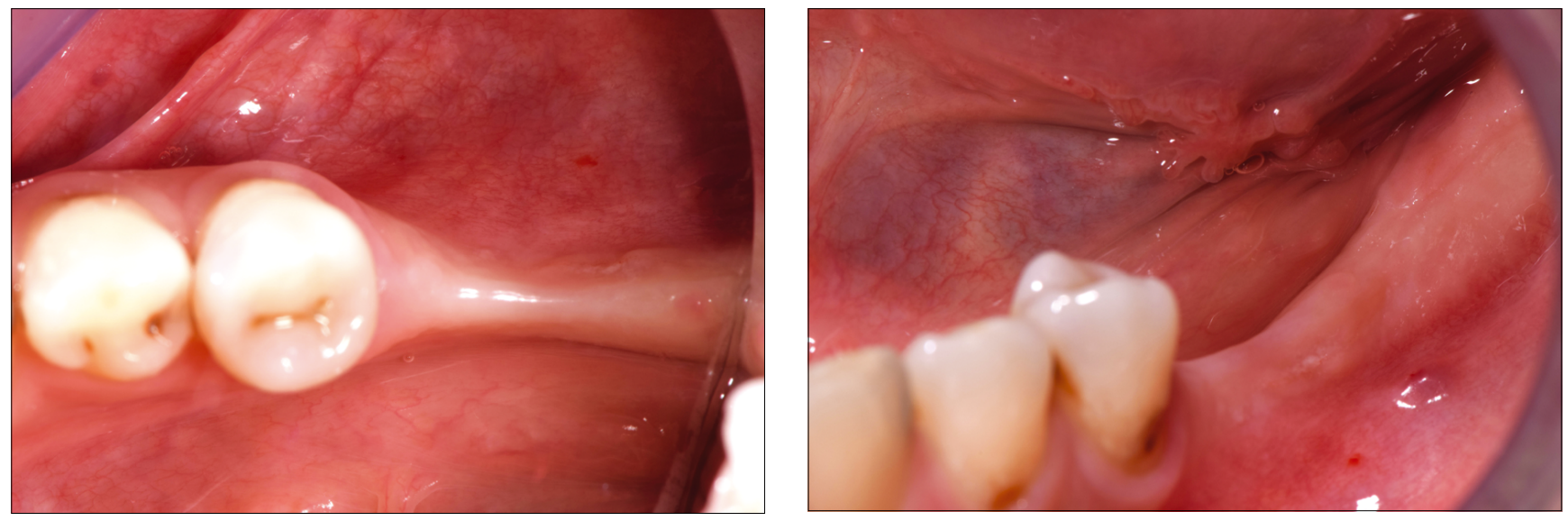

1. $A$ és $B$ kép: Kiindulási klinikai szituáció

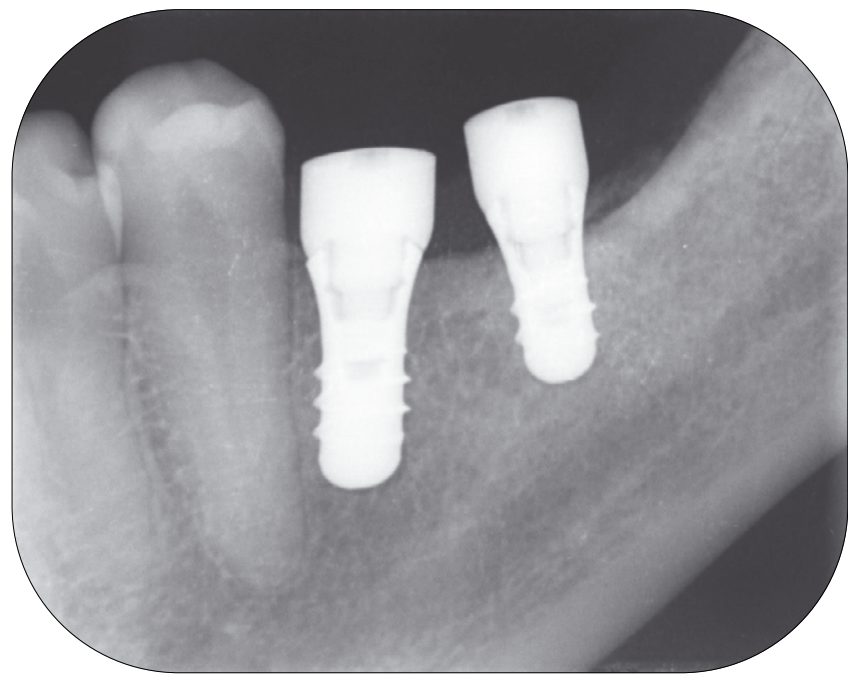

2. kép: Postoperativ periapicalis rtg.

ens nem dohányzó, szisztémásan egészséges, kimondottan jó szájhigiénével rendelkezik, fogágybetegségtől mentes. A CT-vizsgálat eredménye alapján a bal alsó hiányzó molárisok $(36,37)$ területére standard átmérőjü (d: 4,1 mm) rövid (36: $8 \mathrm{~mm}$; 37: $6 \mathrm{~mm}$ ) (Straumann Roxolid) implantátumokat terveztünk behelyezni csavarozott korona felépítménnyel.

Ezzel a megoldással a nehezen kivitelezhető, hoszszú gyógyulási időt igénylő csontpótlás elkerülhetővé vált. A kiindulási szituációban jól látszik a kimondottan vékony mucosa a fogatlan állcsontgerincen, valamint a vékony, nagyjából $2 \mathrm{~mm}$ széles keratinizált mucosa. (1. kép)

A gerincéli metszés a vékony keratinizált sáv közepén történt, hogy mindkét lebenyszél tartalmazza - ha kis mennyiségben is - a keratinizációhoz szükséges sejteket. Az implantátumok behelyezését követően a nagy primer stabilitásnak ( $35 \mathrm{Ncm}$ ) köszönhetően az implantátumokat gyógyulási felépítményekkel láthattuk el a mütét során. (2., 3. kép)

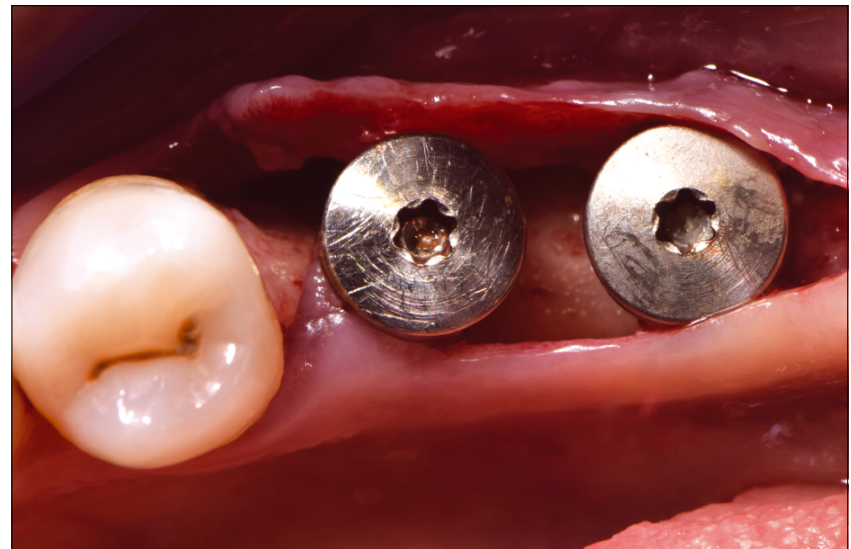

3. kép: Gerincéli metszés

és gyógyulási csavarral ellátott implantátumok, behelyezést követően

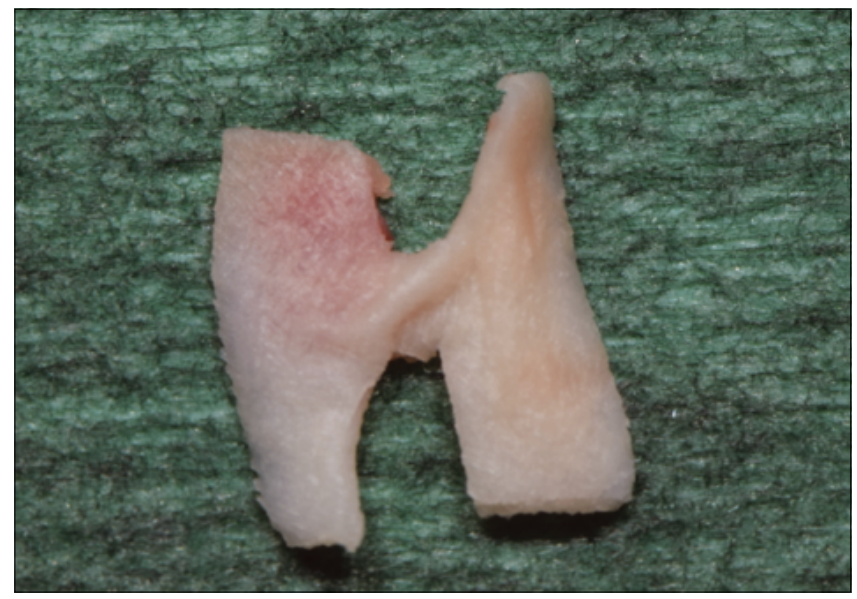

4. kép: „H” alakban megformázott kollagén mátrix

A buccalis, illetve lingualis lebeny nyálkahártyájának megvastagítására, továbbá a lebenyszélek közti keratinizáció elősegítésére kollagén mátrixot (Mucograft $\circledast$, Geistlich Pharma AG, Wolhusen, Switzerland) alkalmaztunk, melyet „H” alakban formáztunk meg. (4. kép) 


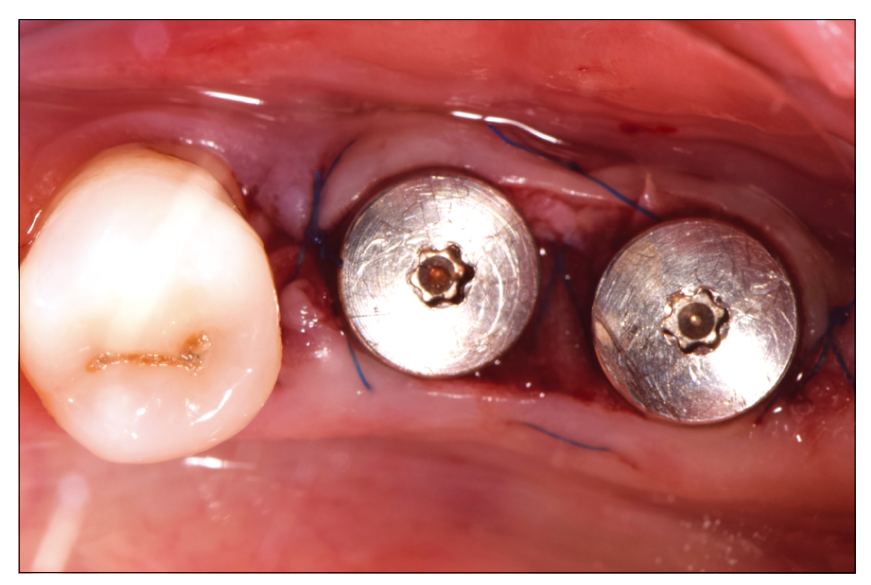

5. kép: Kollagén mátrix, gyógyulási csavarok és matracöltés által immobilizálva

A H alakú kollagén összekötő része fedte a két implantátum között szabadon maradt denudált gerincfelszínt, míg a „H” forma szélső részeit a lebenyszélek alá helyeztük be (tunnel-technikával).

Ily módon a kollagén mátrix egyszerre biztosította a mucosa vastagítását (mind buccalisan, mind lingualisan), valamint a keratinizált szövet szélesítését. A kollagén immobilitását a formája által önmagában nagyrészt a gyógyulási csavarok adták, valamint egy keresztezett horizontális matracöltés az implantátumok között. (5. kép)

\section{Eredmény}

A rövid távú gyógyulás során (varratszedés 2 hét után) már látható a megvastagított biotípus, valamint a kezdődő keratinizáció a szabadon maradt kollagén mátrix felszíneken. (6. kép)

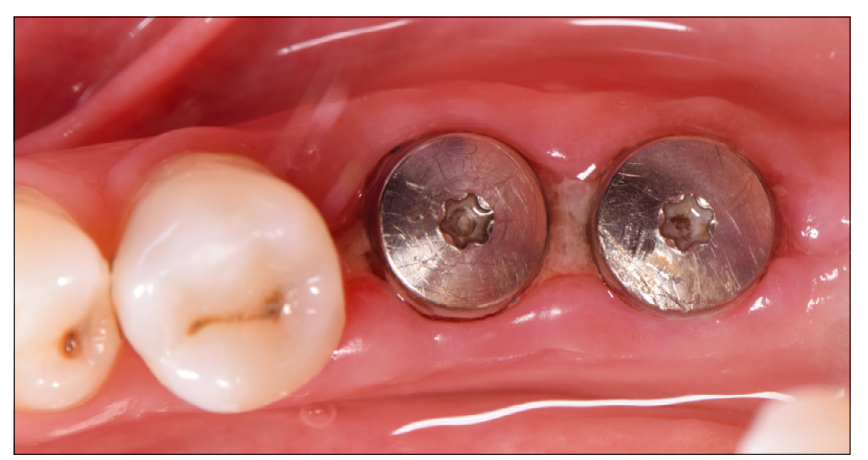

6. kép: Korai gyógyulás -2 hét

A gyógyulás teljes befejeztével (2 hónap) a lágyszövet vastagodása és a keratinizáció kiszélesedése a területen egyértelműen látható, színben, textúrában eltérés a környező szövetektől nincsen, ellentétben a hagyományos szabad íny graft technikánál tapasztalható esetekkel. (7. kép)

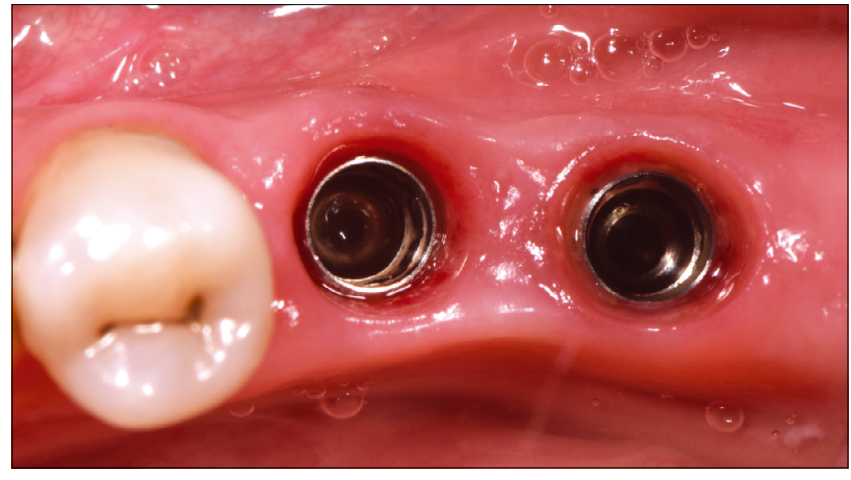

7. kép: Teljes gyógyulás - 2 hónap

Az implantátumokra csavarral rögzített fix fogpótlás került,és 1 éves utánkövetés után is egészséges, stabil és esztétikus lágyszövet profilt tapasztaltunk, az egyéni szájhigiéne a nehezen elérhető terület ellenére is optimális volt. (8. kép)

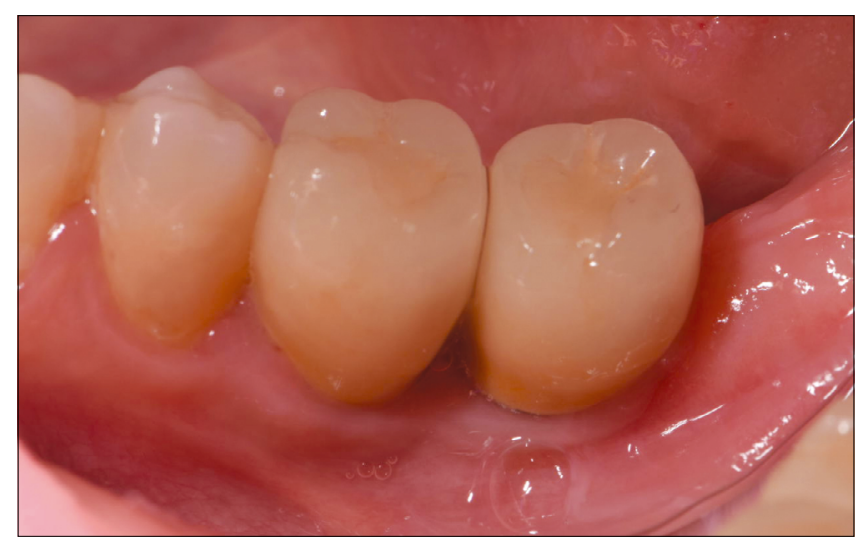

8. kép: Utánkövetés - 1 év

\section{Konklúzió}

Bár ezen technika a bemutatott eseten keresztül ígéretesnek túnik, létjogosultságának igazolásához hosszú távú utánkövetés, nagy esetszám és kontrollcsoporttal való összehasonlítás (ahol nem történt módosítás a periimplantáris lágyszöveteken) szükséges a jövőben.

\section{Irodalom}

1. Barone A, Ricci M, Tonelli P, Santini S, Covani U: Tissue changes of extraction sockets in humans: a comparison of spontaneous healing vs. ridge preservation with secondary soft tissue healing. Clin Oral Implants Res. 2013. Nov. 24. (11): 1231-1237.

2. Bengazi F, Botticelli D, Favero V, Perini A, Urbizo Velez J, Lang NP: Influence of presence or absence of keratinized mucosa on the alveolar bony crest level as it relates to different buccal marginal bone thicknesses. An experimental study in dogs. Clin Oral Implants Res. 2014. Sep. 25. (9): 1065-1071.

3. Chiu YW, Lee SY, LIN YC, LaI YL: Significance of the width of keratinized mucosa on peri-implant health. J Chin Med Assoc. 2015. Jul. 78. (7): 389-394. 
4. Fürhauser R, Florescu D, Benesch T, Haas R, Mailath G, Watzek G: Evaluation of soft tissue around single-tooth implant crowns: the pink esthetic score. Clin Oral Implants Res. 2005. Dec. 16. (6): 639-644

5. Ladwein C, Schmelzeisen R, Nelson K, Fluegge TV, Fretwurst T: Is the presence of keratinized mucosa associated with periimplant tissue health? A clinical cross-sectional analysis. Int J Implant Dent. 2015. Dec. 1. (1): 11.

6. Linkevicius T, Apse P, Grybauskas S, Puisys A: The influence of soft tissue thickness on crestal bone changes around implants: a 1-year prospective controlled clinical trial. Int J Oral Maxillofac Implants. 2009. Jul-Aug. 24. (4): 712-719.

7. Linkevicius T, Puisys A, Linkeviciene L, Peciuliene V, Schlee M: Crestal Bone Stability around Implants with Horizontally Matching Connection after Soft Tissue Thickening: A Prospective Clinical Trial. Clin Implant Dent Relat Res. 2015. Jun. 17. (3): 497-508.

8. Maia LP, Reino DM, Muglia VA, Almeida AL, Nanci A, Wazen RM ET AL: Influence of periodontal tissue thickness on buccal plate remodelling on immediate implants with xenograft. J Clin Periodontol. 2015. Apr. 15.

9. Si MS, Zhuang LF, Huang X, Gu YX, Chou CH, Lal HC: Papillae alterations around single-implant restorations in the anterior maxillae: thick versus thin mucosa. Int J Oral Sci. 2012. Jun. 4. (2): 94-100.

10. Puisys A, Vindasiute E, Linkevciene L, Linkevicius T: The use of acellular dermal matrix membrane for vertical soft tissue augmentation during submerged implant placement: a case series. Clin Oral Implants Res. 2015. Apr. 26. (4): 465-470.
11. Roccuzzo M, Grasso G, Dalmasso P: Keratinized mucosa around implants in partially edentulous posterior mandible: 10-year results of a prospective comparative study. Clin Oral Implants Res. 2015. Feb. 23

12. Rodriguez FR, Paganoni N, Weiger R, Walter C: Lower Educational Level is a Risk Factor for Tooth Loss - Analysis of a Swiss Population (KREBS Project). Oral Health Prev Dent. 2017. 15. (2): 139-145.

13. Schropp L, Wenzel A, Kostopoulos L, Karring T: Bone healing and soft tissue contour changes following single-tooth extraction: a clinical and radiographic 12-month prospective study. Int J Periodontics Restorative Dent. 2003. Aug. 23. (4): 313-323.

14. Schrott AR, Jimenez M, Hwang JW, Fiorellini J, Weber HP: Fiveyear evaluation of the influence of keratinized mucosa on periimplant soft-tissue health and stability around implants supporting full-arch mandibular fixed prostheses. Clin Oral Implants Res. 2009. Oct. 20. (10): 1170-1177.

15. Thoma DS, Mühlemann S, Jung RE: Critical soft-tissue dimensions with dental implants and treatment concepts. Periodontol 2000. 2014. Oct. 66. (1): 106-118.

16. Toljanic JA, Ward CB, Gewerth ME, Banakis ML: A longitudinal clinical comparison of plaque-induced inflammation between gingival and peri-implant soft tissues in the maxilla. J Periodontol. 2001. Sep. 72. (9): 1139-1145.

17. Ueno D, Nagano T, Watanabe T, Shirakawa $S$, Yashima A, Gomi K: Effect of the Keratinized Mucosa Width on the Health Status of Periimplant and Contralateral Periodontal Tissues: A Cross-sectional Study. Implant Dent. 2016. Dec. 25. (6): 796-801.

\section{PÁRKÁNYI L, Fráter M}

\section{Thickening the attached gingiva around implants - the "H-technique" - case presentation}

The soft tissue environment around implants and around the related indirect restoration significantly influences not only the esthetic outcome of the implant-prosthetic solution, but may also influence long term stability of the dental implants. Traditionally biotype modification and thickening or widening the keratinized tissues around implants is carried out during a separate surgical procedure. This can be done either on the appointment of uncovering the implant and placing the healing abutment or later around the already placed healing abutments. The graft used for this specific procedure is usually a free gingival graft (FGG), which can cause significant morbidity to the donor site and also will differ in esthetic appearance from the surrounding soft tissues. The aim of the proposed technique is the simultaneous biotype modification and keratinized tissues augmentation with the aid of acellular dermal matrix (ADM) at the time of implant placement during an open healing. With this technique one should be able to decrease the morbidity of the donor site, reduce the number of surgical interventions and separate surgical steps (leading to reduced healing time) and also improve the esthetic outcome.

Keywords: thickening attached gingiva, ADM, collagen matrix, tunnel technique 